\title{
ГАЗОБЕТОННЫЕ БЛОКИ НА МЕСТНОМ СЫРЬЕ ЧЕЧЕНСКОЙ РЕСПУБЛИКИ
}

\author{
Успанова А.C., \\ Исмаилова 3.X., \\ Киндаров Х-М. У.
} ГГНТУ им. акад. М.Д. Миллионщикова, г. Грозный

Производство строительных материалов сегодня немыслимо без понятий энерго- и ресурсосбережения. Возрастающие темпь строительства жилищно-коммунального хозяйства в Чеченской Республике требуют большого объема высококачественных стеновых материалов. Одними из востребованных стеновых материалов являются изделия из газобетона, которые массово используются в возведении перегородок в многоквартирных домах. Сырьевая база республики достаточна для производства изделий из газобетона, а возрастающие темпы строительно-монтажных работ служат залогом на рынке строительных материалов.

Ключевые слова: газобетон, строительные стеновые материалы, сырьевая база Чеченской Республики.

Развитие технологий производства строительных материалов, изделий и конструкций прогрессирует с каждым днем. Усовершенствуются существующие технологии, внедряются ресурсосберегающие и энергосберегающие технологические приемы, на первый план выходят вопросы экологической безопасности. Проектируя составы строительных композитов, современные исследователи, стараются не только получить низкую себестоимость и высокое качество, но и экологически безвредный для человека и окружающей среды материал. Отельного внимания заслуживает производство стеновых материалов, которое стремительно развивается, осваивая новые сырья и технологий - пенобетоны, газобетоны, силикатные и керамические кирпичи, панели из шлакоцементных композитов и т.п.

Среди широкого спектра строительных стеновых материалов, газобетон занимает отдельную нишу как наиболее востребованный стеновой материал при относительно небольшой массе обладает хорошей теплоизоляцией, паропроницаемостью, достаточной прочностью и легкостью обработки. Производство изделий из газобетона рассредоточено по всему миру и составляет до 60 млн. м $^{3}$ в год. И хотя в начале его открытия он был далек от уровня современного качества, в процессе дальнейших исследований учеными из разных стран, его рецептура приобрела современный вид и необходимые строительно-технические характеристики.

Развитие газобетона прошло путь с 1889 года, когда он был открыт в Чехии исследователем Гоффманом [1], но в силу несовершенства технологий 
тогда не нашел должного применения. В период с 1917 по 1921 годов шведскими учеными были проведены значительные исследования в технологии газобетона, позволившие наладить производство в 1929 году в г. Иксхульт до 15,5 тыс. м $^{3}$ ежегодно. Конечно, тогда не были оптимизированы все свойства газобетона (долговечность, паропроницаемость, водонепроницаемость), но даже при этом он стал массово применяться в строительстве. В дальнейшем развитие газобетона разделилось на сектора: это производство ячеистых бетонов автоклавного твердения и производство газобетона. При этом в качестве вяжущего рассматривались не только цемент, но и смесь цемента с известью, кремнеземистых компонентов, без известковые составы. Все эти исследования очень значимы и положили основу для разработки новых, современных ресурсосберегающих видов газобетона [2].

Сырьевыми материалами для производства газобетона служат цемент, кварцевый песок и специализированные газообразователи (сода, пергидроль, алюминиевая пудра), также применяют известь (вступает в реакцию с алюминиевой пудрой), гипс, золы и шлаки ТЭЦ и различных производств [3]. Все эти сырьевые материалы присутствуют в недрах Чеченской республики. Наиболее разработанным является месторождение кварцевого песка «Червленное», затем «Толстой-Юртовское». В последние годы были исследованы и другие мелкие местные пески Чеченской республики Веденский и Беноевский, относящиеся к очень мелким пескам. Все они могут использоваться в производстве газобетонов при советующей подготовке и обработке, таблица 1.

Таблица 1 - Основные показатели качества местных песков

\begin{tabular}{|c|c|c|c|c|}
\hline \multirow[b]{2}{*}{ Наименование } & \multicolumn{4}{|c|}{ Значения показателей } \\
\hline & $\begin{array}{c}\text { Модуль } \\
\text { крупности, } \\
\text { Мк }\end{array}$ & $\begin{array}{c}\text { Содержание } \\
\text { пылевидных и } \\
\text { глинистых } \\
\text { частиц, \% }\end{array}$ & $\begin{array}{c}\text { Средняя } \\
\text { насыпная } \\
\text { плотность, } \\
\text { кг } / \mathrm{M}^{3} \\
\end{array}$ & $\begin{array}{c}\text { Влажность } \\
\text { песка, \% }\end{array}$ \\
\hline Червленый & 1,9 & 2,4 & 1560 & 20 \\
\hline $\begin{array}{l}\text { Толстой- } \\
\text { Юртовский }\end{array}$ & 1,3 & 1,4 & 1300 & 17 \\
\hline Веденский & 1,4 & 2,2 & 1320 & 19 \\
\hline Беноевский & 1,2 & 2,3 & 1260 & 23 \\
\hline
\end{tabular}

ГУП «Чеченцемент» выпускает портландцемент ПЦ М500, соответствующий ГОСТ 31108-2003 со следующими характеристиками:

- плотностью 3075 кг/ $\mathrm{M}^{3}$;

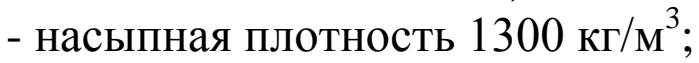

- водопотребность - 20,5\%;

- начало схватывания - 1,25 ч, конец - 6,8 ч.

Также на территории Чеченской республики в посёлке Чири-Юрт налажено производство строительной извести НАО «ИСТ Казбек», 
соответствующая ГОСТ 9179-2018 имеющая следующие характеристики (для 2 сорта), таблица 2:

\begin{tabular}{|c|c|c|}
\hline $\begin{array}{l}\text { № } \\
\text { П/ח }\end{array}$ & Наименование показателя & Значения \\
\hline 1 & Содержание $\mathrm{CaO}+\mathrm{MgO} \%$ & 87,3 \\
\hline 2 & Содержание углекислоты $\left(\mathrm{CO}_{2}\right), \%$ & 2,06 \\
\hline 3 & Время гашения T60 (DIN), мин & 10,33 \\
\hline 4 & Максимальная температура гашения, $\mathrm{C}^{0}$ & 66,1 \\
\hline 5 & Время набора температуры max, минут & 29 \\
\hline 6 & Тонкость помола, $\mathrm{cm}^{2} / \Gamma$ & 3782 \\
\hline 7 & $\begin{array}{l}\text { Остаток частиц на ситах с сеткой, \% } \\
0,2 \text { мм }\end{array}$ & 0,02 \\
\hline & $0,08 \mathrm{Mм}$ & 0,06 \\
\hline
\end{tabular}

Надо отметить, что при СССР на базе Чечено-Ингушского цементного завода, выпускавшего тогда до 1 млн 200 тысяч тонн цемента марки М500, имелось и производство силикатных изделий, в том числе, газосиликатных блоков [4]. Газобетонные блоки массово используются для межкомнатных перегородок в жилищном строительстве, так как обладают следующими характеристиками, таблица 3 :

Таблица 3

\begin{tabular}{|c|c|c|c|}
\hline $\begin{array}{c}\text { № } \\
\Pi / \Pi\end{array}$ & \multicolumn{2}{|c|}{ Наименование } & Значение \\
\hline \multirow[t]{2}{*}{1} & \multirow{2}{*}{ Прочность, кгс/ см² } & автоклав. & $28-40$ \\
\hline & & неавтоклав. & $10-12$ \\
\hline 2 & \multicolumn{2}{|l|}{ Марка плотности } & D350-D1200 \\
\hline 3 & \multicolumn{2}{|l|}{ Водопоглощение, \% } & 20 \\
\hline 4 & \multicolumn{2}{|l|}{ Объемный вес, кг/м ${ }^{3}$} & $400-600$ \\
\hline 5 & \multicolumn{2}{|c|}{ Теплопроводность, Вт (м К) } & $0,09-0,18$ \\
\hline 6 & \multicolumn{2}{|c|}{ Морозостойкость } & F35-F50 \\
\hline 7 & \multicolumn{2}{|l|}{ Огнестойкость, час } & 7 \\
\hline
\end{tabular}

К основным недостаткам безавтоклавного газобетона относятся: значительная усадка (до 0,05 \%), низкая прочность, низкая морозостойкость, при введении в рецептуру специальных добавок и модификаторов данные показатели удается оптимизировать [5].

Вышесказанное позволяет нам сделать вывод о перспективности производства газобетонных и газосиликатных блоков на территории Чеченской Республики. Так, в Шалинском районе Чеченской республики начал функционировать первый технопарк «Казбек», планирующий производить около 300 тысяч м ${ }^{3}$ газобетонных блоков и плит перекрытия, более 30 тыс. тонн извести, около 75 тыс. тонн сухих строительных смесей и около 3 тыс. м² 
фиброцементных изделий в год. Все проектируемые заводы будут использовать местное сырьё и направлены на погашение внутреннего спроса на продукцию.

\section{Исследование выполнено при финансовой поддержке РФФИ в рамках научного проекта № 18-48-200001.}

\section{Список литературы}

1. Горлов, Ю.П., Меркин А.П., Устенко А.А. Технология теплоизоляционных материалов: Монография / Меркин А.П. - Стройиздат, 1980. - 399 c.

2. Кафтаева М.В., Рахимбаев Ш.М., Жуков Д.А., Ковалевская К.Ю., Шугаева М.А., Марушко М.В. Обоснование требований к сырьевым материалам для автоклавного производства газосиликатных бетонов // Современные проблемы науки и образования. - 2014. - № 1.;

3. Баженов, Ю.М. Технология бетона. Монография / Баженов Ю.М. $\mathrm{ACB}, 2007 .-528 \mathrm{c}$.

4. Батаева Я.Д., Исраилов М.В., Исраилов М.В. Тенденции развития промышленного сектора экономики Чеченской Республики // Фундаментальные исследования. 2012. № 11-2. - С. 488-492.

5. Жуков, А.Д., Чугунков А.В., Химич О.А., Еременко А.А., Копылов Н.А. Комплексный анализ в технологии газобетона // Вестник МГСУ, 2013, С. 167-175. 